\title{
PENDIDIKAN KARAKTER ANAK DENGAN METODE WHOLE BRAIN TEACHING DALAM PEMBELAJARAN DI BIMBINGAN BELAJAR PENCIL GENERATION DI LINGKUNGAN V SIMALINGKAR B MEDAN TUNTUNGAN
}

\author{
Juli Loisiana Butar-butar* ${ }^{1}$, Ferdinand Sinuhaji ${ }^{2}$, Jenita Anjani br. Sembiring ${ }^{3}$ \\ ${ }^{1,2}$ Fakultas Matematika dan Ilmu Pengetahuan Alam, Universitas Quality Berastagi \\ ${ }^{3}$ Fakultas Keguruan dan Ilmu Pendidikan, Universitas Quality Berastagi \\ email: julois.butrz@gmail.com
}

\begin{abstract}
The environment greatly influences the establishment of human character and large urban suburbs are areas inhabited majority by the lower middle class. The main goal in community service is to provide character education through free tutoring for Mathematics and English for primary school in course center Pencil Generation in Zone V Simalingkar B Sub-District Medan Tuntungan North Sumatera. The method used in process of the character education is the Whole Brain Teaching (WBT) method which is integrated during the teaching and learning process in the course center. The steps taken by the team in order to carry out this activity are as follows: (1). preparation for service activities, (2). provide guidance about characters, (3). forming learning groups based on class, (4). guide children to learn with the Whole Brain Teaching method, (5). sometimes play games related to Mathematics and English. The result of this service is academic improvement in Mathematics and English. Beside the academic improvement, there is also an increase in character that is manners, perseverance, discipline, tolerance, and caring.
\end{abstract}

Keywords : Character Education, Whole Brain Teaching.

\begin{abstract}
Abstrak
Lingkungan sangat mempengaruhi pembentukan karakter manusia dan daerah pinggiran kota besar merupakan kawasan yang dihuni mayoritas oleh kalangan menengah ke bawah. Tujuan utama dalam pengabdian kepada masyarakat ini adalah memberikan pendidikan karakter melalui bimbingan belajar (bimbel) gratis untuk mata pelajaran Matematika dan Bahasa Inggris untuk anak-anak SD Bimbingan Belajar Pencil Generation di .Lingkungan V Kelurahan Simalingkar B Kecamatan Medan Tuntungan Sumatera Utara. Metode yang dipakai dalam proses pendidikan karakter ini adalah metode Whole Brain Teaching (WBT) yang diintegrasikan saat proses belajar mengajar di bimbel. Langkah-langkah yang dilakukan oleh tim dalam rangka melaksakan kegiatan ini adalah sebagai berikut: (1). persiapan untuk kegiatan pengabdian, (2). memberikan bimbingan tentang karakter, (3). membuat kelompok belajar berdasarkan kelas, (4). membimbing anak belajar dengan metode Whole Brain Teaching, dan (5). Ada kalanya memainkan permainan yang berhubungan dengan Matematika dan Bahasa Inggris. Hasil kegiatan adalah adanya peningkatan akademis Matematika dan Bahasa Inggris. Selain peningkatan akademis juga ada peningkatan dalam karakter yaitu sopan santun, ketekunan, kedisiplinan, toleransi, dan rasa peduli.
\end{abstract}

Kata kunci: Pendidikan Karakter, Whole Brain Teaching.

\section{PENDAHULUAN}

Lingkungan sangat mempengaruhi pembentukan karakter manusia. Pendidikan merupakan salah satu bagian dari faktor lingkungan pembentukan karakter. Lingkungan masyarakat kelas bawah merupakan lingkungan sangat rentan 
mengalami kegagalan pembentukan karakter individu.

Daerah pinggiran kota besar merupakan kawasan yang dihuni oleh mayoritas kalangan menengah ke bawah. Lingkungan V Kelurahan Simalingkar B Kecamatan Medan Tuntungan yang berbatasan dengan Kabupaten Deliserdang merupakan salah satu lokasi yang penghuni cukup salah satu contoh daerah pinggiran kota medan.

Mitra dalam program pengabdian kepada masyarakat ini adalah Bimbingan Belajar Pencil Generation yang berada di .Lingkungan V Kelurahan Simalingkar B ini merupakan salah satu lokasi yang penghuninya cukup banyak merupakan keluarga kalangan menengah ke bawah. Suatu komunitas yang bernama Pencil Generation berdiri untuk membantu anakanak lingkungan tersebut berupa bimbingan belajar (bimbel) gratis. Komunitas terdiri para alumni dari berbagai universitas yang semua anggotanya sudah bekerja.

Selama ini, proses belajar mengajar dilakukan di depan rumah warga atau di depan rumah anak-anak yang mengikuti bimbel. Lokasi belajar yang tidak tetap dan kurangnya tim pengajar menjadi kendala utama dari bimbingan belajar ini.

Pengabdian kepada masyarakat ini hadir dan membantu kendala dari Pencil Generation dengan turut serta mengambil bagian menjadi tim pengajar dari bimbel untuk anak-anak SD yang diadakan oleh komunitas ini.

Alasan pengadian kepada masyarakat ini memilih mata pelajaran matematika adalah karena merupakan mata pelajaran yang dipelajari dari pendidikan usia dini bahkan perguruan tinggi dan mengajarkan seseorang berpikir logis, kritis, analisis, sistematis, dan kreatif. Matematika sangat berkaitan dengan kehidupan sehari-hari sehingga mata pelajaran ini dapat diimplementasikan untuk membantu pendidikan karakter anak [1].

Menurut [2], untuk dapat merancang pembelajaran Matematika yang dapat menunjang atau mengembangkan pendidikan karakter, maka perlu identifikasi unsur-unsur atau komponenkomponen yang ada dalam pembelajaran. Nilai-nilai yang dikembangkan dalam pendidikan budaya dan karakter bangsa yang bersumber dari Agama, Pancasila, Budaya, dan Tujuan Pendidikan Nasional [3]. Oleh karena itu, tim pelaksana juga mengajarkan nilai-nilai tersebut sebelum proses belajar mengajar.

Selain Matematika, Bahasa Inggris dipilih dikarenakan merupakan Bahasa international yang saat harus dikembangkan. Nilai-nilai pendidikan karakter yang dapat ditanamkan pada mata pelajaran bahasa Inggris adalah bersahabat atau komunikatif, peduli sosial, rasa ingin tahu, demokratis, mandiri, kerja keras, disiplin, dan senang membaca [4]. Berkomunikasi yang sederhana merupakan cara yang dapat digunakan anak-anak dalam mempelajari bahasa Inggris [5].

Metode pembelajaran yang diterapkan untuk menyelesaikan permasalahan bimbel Pencil Generation ini adalah Whole Brain Teaching [6]. Para pengajar lebih banyak berinteraksi langsung dengan anak-anak bimbel.

\section{METODE PENGABDIAN}

Langkah pelaksanaan dalam proses pendampingan program pengabdian pada masyarakat untuk anak-anak tingkat sekolah dasar ke bawah ini, yaitu

1. Membimbing anak belajar dengan metode Whole Brain Teaching

2. Memberikan bimbingan karakter secara singkat

3. Membuat kelompok belajar berdasarkan kelas.

4. Memainkan permainan yang berhubungan dengan Matematika dan bahasa inggris.

Langkah-langkah pembelajaran whole brain teaching ini dapat divariasikan sesuai dengan kebutuhan di dalam kelas. Hal yang paling utama dalam kegiatan ini adalah komunikasi aktif antara pengajar dan anakanak. 
Adapun bimbel dilaksanakan sebanyak 25 kali pertemuan selama 3 bulan dengan pembelajaran mata pelajaran Matematika dan Bahasa Inggris akan berselang-seling dilakukan. Setiap pertemuan, satu kelompok belajar akan dibimbing oleh satu orang pengajar. Untuk lebih jelas mengenai metode pelaksanaan yang akan dilakukan, perhatikan gambar 1 berikut.

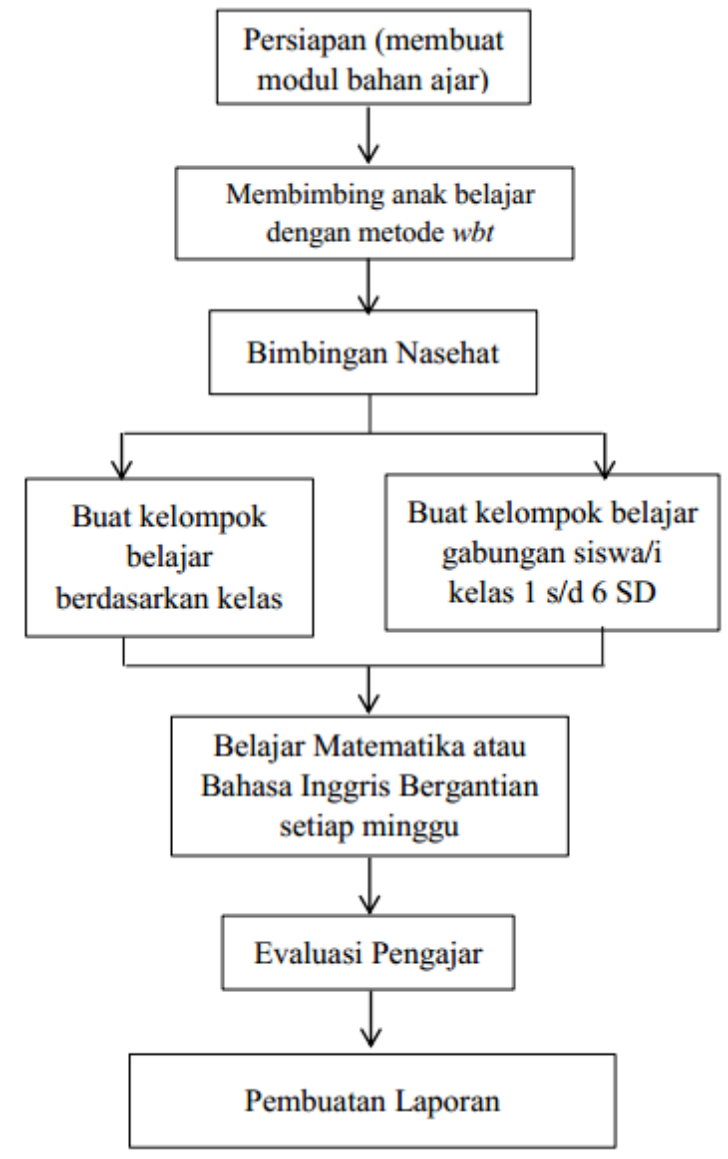

Gambar 1. Diagram Alir Pengabdian Kepada Masyarakat

\section{HASIL DAN PEMBAHASAN}

Pendidikan karakter merupakan satusatunya cara terbaik untuk membantu anakanak dari golongan menengah ke bawah dari lingkungan dalam era globalisasi ini. Namun, mengajarkan pendidikan karakter langsung kepada anak-anak mungkin memang memberikan efek jenuh kepada para peserta didik. Cara yang lebih efisien adalah dengan mengintegrasikan Mata Pelajaran yang akan diajarkan dengan pendidikan karakter.

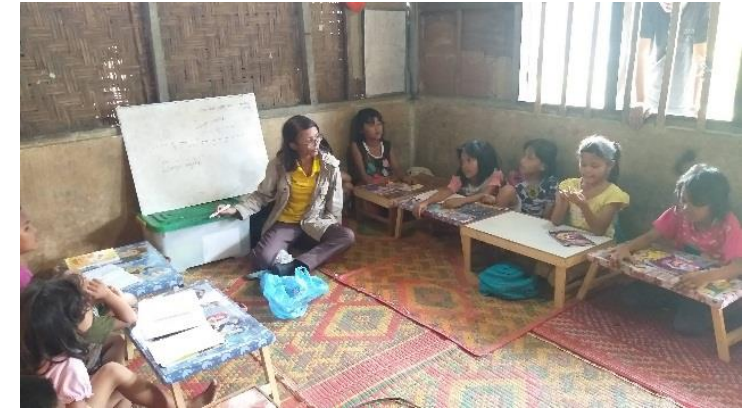

Gambar 2. Memberikan Bimbingan karakter kepada peserta.

Berikut ini adalah karakter-karakter penting yang harus diajarkan.

Tabel 1. Karakter yang Diajarkan

\begin{tabular}{|l|l|}
\hline No. & Karakter \\
\hline a. & Bersyukur \\
\hline b. & Jujur \\
\hline c. & Disiplin \\
\hline d. & Terbuka \\
\hline e. & Toleransi \\
\hline f. & Bernalar \\
\hline g. & Kreatif \\
\hline h. & Peduli \\
\hline i. & Tanggung Jawab \\
\hline j. & Keteraturan \\
\hline k. & Santun \\
\hline l. & Gotong Royong \\
\hline m. & Gigih \\
\hline n. & Analitis \\
\hline o. & Teliti \\
\hline p. & Kreativitas \\
\hline q. & Kritis \\
\hline r. & Kerajinan \\
\hline s. & Daya, upaya, usaha \\
\hline t. & Inovatif \\
\hline u. & Daya tahan, Keuletan \\
\hline v. & Kepercayaan diri \\
\hline
\end{tabular}

Pengajaran secara konvensional cenderung membosankan bagi anaka-anak. Dalam pelaksanaan kegiatan ini sangatlah perlu ekstra kesabaran dari para pengajar. Prioritas utama dari kegiatan pengabdian kepada masyarakat ini adalah pendidikan yang diimplementasikan dalam mata pelajaran Matematika dan Bahasa Inggris. Untuk lebih jelas perhatikan tabel 2 dan 
tabel 3 berikut dengan karakter berdasarkan tabel 1 .

Tabel 2. Materi Pelajaran Matematika dan Implementasi Karakter

\begin{tabular}{|r|l|l|}
\hline No. & $\begin{array}{l}\text { Materi Pelajaran } \\
\text { Matematika SD }\end{array}$ & $\begin{array}{l}\text { Implementasi } \\
\text { Karakter }\end{array}$ \\
\hline 1 & Bilangan & $\mathrm{a}, \mathrm{b}$ \\
\hline 2 & Penjumlahan & $\mathrm{a}, \mathrm{b}$ \\
\hline 3 & Pengurangan & $\mathrm{a}$ \\
\hline 4 & Perkalian Biasa & $\mathrm{f}, \mathrm{m}, \mathrm{s}$ \\
\hline 5 & Pembagian Biasa & $\mathrm{h}, \mathrm{s}$ \\
\hline 6 & Perkalian Bersusun & $\mathrm{j}, \mathrm{m}, \mathrm{o}, \mathrm{s}, \mathrm{u}$ \\
\hline 7 & $\begin{array}{l}\text { Pembagian } \\
\text { Bersusun }\end{array}$ & $\mathrm{h}, \mathrm{j}, \mathrm{o}, \mathrm{s}, \mathrm{u}$ \\
\hline 8 & Pengukuran Jarak & $\mathrm{d}, \mathrm{h}$, \\
\hline 9 & Pengukuran Waktu & $\mathrm{c}, \mathrm{i}$, \\
\hline 10 & Pengukuran Sudut & $\mathrm{g}, \mathrm{h}, \mathrm{o}$, \\
\hline 11 & $\begin{array}{l}\text { Keliling dan Luas } \\
\text { Bangun Datar }\end{array}$ & $\mathrm{g}, \mathrm{h}, \mathrm{o}, \mathrm{n}$ \\
\hline 12 & $\begin{array}{l}\text { Polume dan Luas } \\
\text { Rermukaan Bangun }\end{array}$ & $\mathrm{g}, \mathrm{h}, \mathrm{o}, \mathrm{n}$ \\
\hline 13 & Pecahan & $\mathrm{n}, \mathrm{t}$ \\
\hline 14 & Pengukuran Massa & $\mathrm{a}, \mathrm{b}, \mathrm{i}, \mathrm{o}$ \\
\hline 15 & KPK & $\mathrm{f}, \mathrm{o}$, \\
\hline 16 & FPB & $\mathrm{f}, \mathrm{o}$ \\
\hline 17 & Bilangan Romawi & $\mathrm{j}, \mathrm{t}$ \\
\hline 18 & $\begin{array}{l}\text { Kesebangunan dan } \\
\text { Simetri }\end{array}$ & $\mathrm{g}, \mathrm{o}, \mathrm{q}$ \\
\hline 19 & Pangkat & $\mathrm{m}, \mathrm{o}, \mathrm{s}, \mathrm{u}$ \\
\hline 20 & Akar & $\mathrm{f}, \mathrm{m}, \mathrm{s}, \mathrm{u}$ \\
\hline 21 & Bidang Koordinat & $\mathrm{c}, \mathrm{j}, \mathrm{n}, \mathrm{o}$ \\
\hline 22 & $\begin{array}{l}\text { Penyajian dan } \\
\text { Pengolahan Data }\end{array}$ & $\mathrm{b}, \mathrm{q}$ \\
\hline & & \\
\hline
\end{tabular}

Tabel 3. Materi Pelajaran Bahasa Inggris dan Implementasi Karakter

\begin{tabular}{|r|l|l|}
\hline No & $\begin{array}{c}\text { Materi } \\
\text { Pelajaran } \\
\text { Bahasa Inggris }\end{array}$ & $\begin{array}{c}\text { Implementasi } \\
\text { Karakter }\end{array}$ \\
\hline 1 & Spelling & $\mathrm{d}, \mathrm{m}, \mathrm{s}, \mathrm{v}$ \\
\hline 2 & Reading & $\mathrm{d}, \mathrm{m}, \mathrm{v}, \mathrm{f}$ \\
\hline 3 & Memorizing & $\mathrm{c}, \mathrm{m}, \mathrm{s}, \mathrm{v}$ \\
\hline & $\begin{array}{l}\text { Speaking/ } \\
\text { Conversation }\end{array}$ & $\mathrm{d}, \mathrm{e}, \mathrm{h}$ \\
\hline
\end{tabular}

\begin{tabular}{|c|l|l|}
5 & Writing & $\mathrm{j}, \mathrm{m}, \mathrm{o}$ \\
\hline 6 & Listening & $\mathrm{h}, \mathrm{s}, \mathrm{u}$ \\
\hline \multicolumn{2}{|c|}{ Untuk materi bahasa Inggris }
\end{tabular}
dikombinasikan juga dengan nilai karakter pada tabel 1 .

Metode yang dipakai adalah Whole Brain Teaching [6] dengan langkahlangkah dan karakter yang dibentuk dapat dilihat dalam tabel 4.

Tabel 4. Langkah-langkah Metode Pembelajaran Power Teaching dan Karakter yang Dibentuk

\begin{tabular}{|c|c|c|c|}
\hline $\begin{array}{l}\mathbf{N} \\
\mathbf{0 .}\end{array}$ & $\begin{array}{l}\text { Lang- } \\
\text { kah }\end{array}$ & Fungsi & $\begin{array}{c}\text { Karak- } \\
\text { ter yang } \\
\text { Diben- } \\
\text { tuk }\end{array}$ \\
\hline 1. & $\begin{array}{l}\text { Class } \\
\text { "Yes" }\end{array}$ & $\begin{array}{l}\text { Penarik } \\
\text { perhatian }\end{array}$ & $\begin{array}{l}\text { hormat, } \\
\text { fokus }\end{array}$ \\
\hline 2. & $\begin{array}{l}\text { Class- } \\
\text { room } \\
\text { rules }\end{array}$ & $\begin{array}{l}\text { Pengorgan } \\
\text { isasian } \\
\text { kelas }\end{array}$ & $\begin{array}{l}\text { disiplin, } \\
\text { tegas }\end{array}$ \\
\hline 3. & $\begin{array}{l}\text { Teach } \\
\text { "Okay" }\end{array}$ & $\begin{array}{l}\text { Pengaktiv- } \\
\text { asi seluruh } \\
\text { bagian } \\
\text { otak }\end{array}$ & $\begin{array}{l}\text { cerdas, } \\
\text { cermat }\end{array}$ \\
\hline 4. & $\begin{array}{l}\text { The } \\
\text { Score- } \\
\text { board }\end{array}$ & Motivator & $\begin{array}{l}\text { memba- } \\
\text { ngun } \\
\text { motivasi } \\
\text { untuk diri } \\
\text { sendiri }\end{array}$ \\
\hline 5. & $\begin{array}{l}\text { Hands } \\
\text { and eyes }\end{array}$ & $\begin{array}{l}\text { Penekanan } \\
\text { /pemfokus } \\
\text { perhatian }\end{array}$ & $\begin{array}{l}\text { kerja } \\
\text { keras, } \\
\text { peduli }\end{array}$ \\
\hline 6. & Switch & $\begin{array}{l}\text { Pengem- } \\
\text { bangan } \\
\text { aktivitas } \\
\text { mende- } \\
\text { ngar dan } \\
\text { berbicara }\end{array}$ & $\begin{array}{l}\text { percaya } \\
\text { diri, } \\
\text { toleran, } \\
\text { sabar }\end{array}$ \\
\hline
\end{tabular}

Hal yang paling dihindari dari proses belajar mengajar dalam kegiatan ini adalah model pembelajaran konvensional yang didominasi kegiatan guru membuat siswa menjadi pasif sehingga siswa merasa jenuh dalam menerima pelajaran. Penggagas metode pembelajaran WBT Chriss Biffle dalam [7] menyajikan pembelajaran 
karakter dalam kehidupan sehari-hari. Interaksi yang aktif antara pengajar dan anak-anak membuat anak-anak lebih semangat dalam belajar.

Menurut [8], tindakan yang dilakukan terangkum terdapat empat langkah penelitian yaitu perencanaan, tindakan, pengamatan/observasi, dan refleksi. Dengan melakukan hal-hal tersebut pelaksanaan akan berjalan optimal.

Beberapa contoh kegiatan pembelajaran matematika yang membangun karakter yang dilakukan saat kegiatan PKM di Pencil Generation:

1. Pengajar menuliskan garis bilangan dari bilangan negatif sampai dengan positif. Pengajar menanyakan hal-hal baik yang harus dilakukan kepada para peserta seperti mengasihi, rajin, sopan, jujur, dan lain sebagainya. Kemudian pengajar mengatakan halhal baik ini adalah hal-hal positif yang harus dilakukan. Sedangkan lawan dari hal-hal baik itu yaitu, tidak mengasihi (membenci), tidak rajin (malas), tidak sopan (kasar), tidak jujur (bohong), dan lain sebagainya merupakan hal-hal negatif yang tidak boleh dilakukan.

2. Pengajar menulis soal penjumlahan dengan bilangan ratusan, puluhan dan ribuan seperti $127+23+8706$. Pengajar menanyakan bagaimana cara mengerjakan soal tersebut. Peserta menjawab dengan cara bersusun ke bawah. Lalu pengajar menuliskan beberapa cara penyelesaian seperti berikut.

\begin{tabular}{|l|l|r|}
\hline 127 & 127 & 127 \\
23 & 23 & 23 \\
8706 & 8706 & 8706 \\
\hline & & \\
\hline a. & b. & c. \\
\hline
\end{tabular}

Anak-anak sepakat bahwa cara yang benar adalah c tetapi banyak yang tidak tahu kenapa bisa seperti itu. Kemudian pengajar menjelaskan bahwa bilangan satuan, bilangan puluhan, bilangan ratusan, dan bilangan ribuan haruslah ditulis dengan sejajar. Dari hal ini pengajar mengajarkan tentang keteraturan seperti halnya yang mereka dapat saat baris-berbaris.

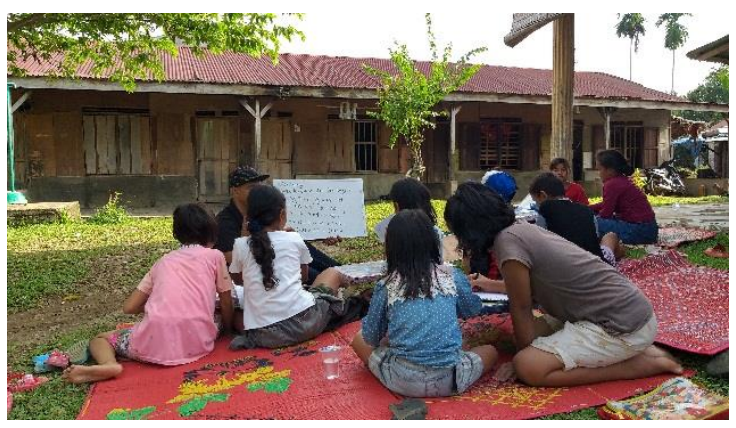

Gambar 3. Belajar Matematika bersama peserta

Beberapa contoh kegiatan pembelajaran Bahasa Inggris yang membangun karakter yang dilakukan saat kegiatan PKM di Pencil Generation:

1. Pengajar mendorong peserta untuk mampu memperkenalkan diri dalam bahasa Inggris. Karena Perkenalan diri membutuhkan kepercayaan diri dan dapat digunakan untuk mengetahui bagaimana orang mencoba untuk menjelaskan tentang diri mereka kepada orang lain secara khusus [9]. Ini dimulai dengan pengajar yang terlebih dahulu memperkenalkan dirinya dalam Bahasa Inggris

2. Pengajar membacakan beberapa kata atau suatu kalimat untuk diikuti peserta. Pengajar menunjuk anak satu persatu untuk membaca ulang dengan pelafalan yag sesuai dengan diajarkan. Kebanyakan anak-anak tidak langsung secara baik mengucapkannya. Tetapi dengan pengulangan kembali dilakukan oleh pengajar akhirnya peserta dapat mengucapkannya dengan benar. Pendidikan karakter yang pengajar terapkan saat melakukan ini adalah kepercayaan diri dan kegigihan.

3. Pengajar mengajak anak-anak bernyanyi dalam lagu bahasa Inggris seperti lagu "A B C", "I Love You", "Head-Shoulder-Knees-and-Toes" dan sebagainya. Sambil menyanyikan 
ISSN : 2550-0198

lagu anak-anak diajak untuk aktif dan terbuka untuk mengekspresikan dirinya.

4. Pengajar berkomunikasi dengan peserta dengan menanyakan hal-hal baik yang pernah mereka lakukan dalam bahasa Inggris. Peserta kebanyakan tidak tahu mengucapkannya dalam bahasa Inggris tetapi mereka mengatakan dalam bahasa Indonesia dan pengajar menerjemahkannya ke dalam bahasa Inggris.

Pengajar: Hello, Class. What kindness have you ever done?

Peserta 1: Sweeping the floor.

Peserta 2: Sittering my little brother.

Peserta 3: Cleaning the dishes.

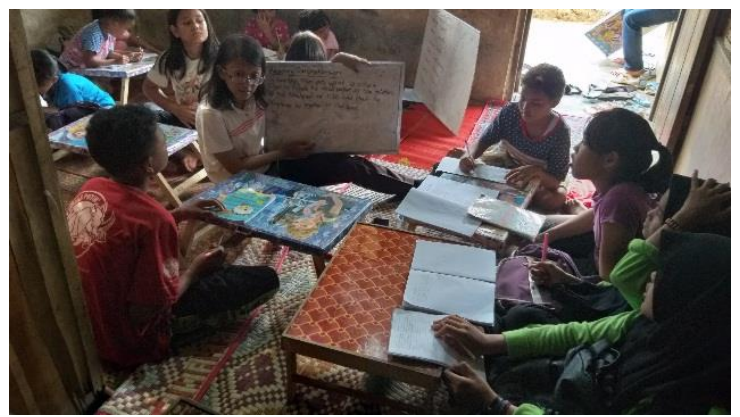

Gambar 4. Belajar Bahasa Inggris bersama peserta

Banyak lagi hal lain yang dilakukan seperti kedua contoh di atas. Hal yang paling utama adalah mengajak anak untuk aktif, komunikatif dan tidak malu mengungkapkan pendapatnya.

Setelah kegiatan pengabdian PKM ini dilaksanakan berikut ini adalah hasil evaluasi per kelas yang diperoleh dalam hal akademik dan karakter. Penilaian karakter yang diutamkan adalah sopan santun, ketekunan, kedisiplinan, toleransi, dan rasa peduli.
Tabel 5. Evaluasi Kelas 1 SD

\begin{tabular}{|c|l|c|c|}
\hline No. & \multicolumn{1}{|c|}{$\begin{array}{c}\text { Hal yang } \\
\text { Dievaluasi }\end{array}$} & $\begin{array}{c}\text { Sebelum } \\
\text { PKM }\end{array}$ & $\begin{array}{c}\text { Setelah } \\
\text { PKM }\end{array}$ \\
\hline 1 & $\begin{array}{l}\text { Kemampuan } \\
\text { Akademik } \\
\text { Matematika }\end{array}$ & 2 & 4 \\
\hline 2 & $\begin{array}{l}\text { Kemampuan } \\
\text { Akademik } \\
\text { Bahasa Inggris }\end{array}$ & 1 & 4 \\
\hline 3 & $\begin{array}{l}\text { Karakter Sopan } \\
\text { Santun }\end{array}$ & 3 & 4 \\
\hline 4 & $\begin{array}{l}\text { Karakter } \\
\text { ketekunan }\end{array}$ & 3 & 4 \\
\hline 5 & $\begin{array}{l}\text { Karakter } \\
\text { Kedisiplinan }\end{array}$ & 2 & 4 \\
\hline 6 & $\begin{array}{l}\text { Karakter } \\
\text { Toleransi }\end{array}$ & 2 & 4 \\
\hline 7 & $\begin{array}{l}\text { Karakter Rasa } \\
\text { Peduli }\end{array}$ & 3 & 4 \\
\hline
\end{tabular}

Tabel 6. Evaluasi Kelas 2 SD

\begin{tabular}{|c|c|c|c|}
\hline No. & $\begin{array}{c}\text { Hal yang } \\
\text { Dievaluasi }\end{array}$ & $\begin{array}{l}\text { Sebelum } \\
\text { PKM }\end{array}$ & $\begin{array}{c}\text { Setelah } \\
\text { PKM }\end{array}$ \\
\hline 1 & $\begin{array}{l}\text { Kemampuan } \\
\text { Akademik } \\
\text { Matematika }\end{array}$ & 2 & 4 \\
\hline 2 & $\begin{array}{l}\text { Kemampuan } \\
\text { Akademik } \\
\text { Bahasa Inggris }\end{array}$ & 2 & 4 \\
\hline 3 & $\begin{array}{l}\text { Karakter Sopan } \\
\text { Santun }\end{array}$ & 2 & 5 \\
\hline 4 & $\begin{array}{l}\text { Karakter } \\
\text { ketekunan }\end{array}$ & 3 & 5 \\
\hline 5 & $\begin{array}{l}\text { Karakter } \\
\text { Kedisiplinan }\end{array}$ & 2 & 4 \\
\hline 6 & $\begin{array}{l}\text { Karakter } \\
\text { Toleransi }\end{array}$ & 2 & 4 \\
\hline 7 & $\begin{array}{l}\text { Karakter Rasa } \\
\text { Peduli }\end{array}$ & 2 & 4 \\
\hline
\end{tabular}

Tabel 7. Evaluasi Kelas 3 SD

\begin{tabular}{|c|l|c|c|}
\hline No. & \multicolumn{1}{|c|}{$\begin{array}{c}\text { Hal yang } \\
\text { Dievaluasi }\end{array}$} & $\begin{array}{c}\text { Sebelum } \\
\text { PKM }\end{array}$ & $\begin{array}{c}\text { Setelah } \\
\text { PKM }\end{array}$ \\
\hline 1 & $\begin{array}{l}\text { Kemampuan } \\
\text { Akademik } \\
\text { Matematika }\end{array}$ & 2 & 4 \\
\hline 2 & $\begin{array}{l}\text { Kemampuan } \\
\text { Akademik } \\
\text { Bahasa Inggris }\end{array}$ & 2 & 4 \\
\hline
\end{tabular}


ISSN : 2550-0198

\begin{tabular}{|c|l|c|c|}
\hline 3 & $\begin{array}{l}\text { Karakter Sopan } \\
\text { Santun }\end{array}$ & 2 & 3 \\
\hline 4 & $\begin{array}{l}\text { Karakter } \\
\text { ketekunan }\end{array}$ & 3 & 3 \\
\hline 5 & $\begin{array}{l}\text { Karakter } \\
\text { Kedisiplinan }\end{array}$ & 2 & 3 \\
\hline 6 & $\begin{array}{l}\text { Karakter } \\
\text { Toleransi }\end{array}$ & 2 & 3 \\
\hline 7 & $\begin{array}{l}\text { Karakter Rasa } \\
\text { Peduli }\end{array}$ & 2 & 3 \\
\hline
\end{tabular}

Tabel 8. Evaluasi Kelas 4 SD

\begin{tabular}{|c|l|c|c|}
\hline No. & \multicolumn{1}{|c|}{$\begin{array}{c}\text { Hal yang } \\
\text { Dievaluasi }\end{array}$} & $\begin{array}{c}\text { Sebelum } \\
\text { PKM }\end{array}$ & $\begin{array}{c}\text { Setelah } \\
\text { PKM }\end{array}$ \\
\hline 1 & $\begin{array}{l}\text { Kemampuan } \\
\text { Akademik } \\
\text { Matematika }\end{array}$ & 2 & 4 \\
\hline 2 & $\begin{array}{l}\text { Kemampuan } \\
\text { Akademik } \\
\text { Bahasa Inggris }\end{array}$ & 2 & 4 \\
\hline 3 & $\begin{array}{l}\text { Karakter Sopan } \\
\text { Santun }\end{array}$ & 3 & 4 \\
\hline 4 & $\begin{array}{l}\text { Karakter } \\
\text { ketekunan }\end{array}$ & 4 & 5 \\
\hline 5 & $\begin{array}{l}\text { Karakter } \\
\text { Kedisiplinan }\end{array}$ & 3 & 4 \\
\hline 6 & $\begin{array}{l}\text { Karakter } \\
\text { Toleransi }\end{array}$ & 3 & 5 \\
\hline 7 & $\begin{array}{l}\text { Karakter Rasa } \\
\text { Peduli }\end{array}$ & 4 & \\
\hline
\end{tabular}

\begin{tabular}{l|l|l|l}
7 & $\begin{array}{l}\text { Karakter Rasa } \\
\text { Peduli }\end{array}$ & 4 & 5 \\
\hline
\end{tabular}

Tabel 10. Evaluasi Kelas 6 SD

\begin{tabular}{|c|l|c|c|}
\hline No. & \multicolumn{1}{|c|}{$\begin{array}{c}\text { Hal yang } \\
\text { Dievaluasi }\end{array}$} & $\begin{array}{c}\text { Sebelum } \\
\text { PKM }\end{array}$ & $\begin{array}{c}\text { Setelah } \\
\text { PKM }\end{array}$ \\
\hline 1 & $\begin{array}{l}\text { Kemampuan } \\
\text { Akademik } \\
\text { Matematika }\end{array}$ & 2 & 4 \\
\hline 2 & $\begin{array}{l}\text { Kemampuan } \\
\text { Akademik } \\
\text { Bahasa Inggris }\end{array}$ & 2 & 4 \\
\hline 3 & $\begin{array}{l}\text { Karakter Sopan } \\
\text { Santun }\end{array}$ & 3 & 4 \\
\hline 4 & $\begin{array}{l}\text { Karakter } \\
\text { ketekunan }\end{array}$ & 3 & 4 \\
\hline 5 & $\begin{array}{l}\text { Karakter } \\
\text { Kedisiplinan }\end{array}$ & 2 & 4 \\
\hline 6 & $\begin{array}{l}\text { Karakter } \\
\text { Toleransi }\end{array}$ & 2 & 4 \\
\hline 7 & $\begin{array}{l}\text { Karakter Rasa } \\
\text { Peduli }\end{array}$ & 3 & 4 \\
\hline
\end{tabular}

Keterangan tabel: nilai adalah $1=$ buruk, 2 = cukup buruk, $3=$ cukup baik, $4=$ baik, 5 = sangat baik.

Berdasarkan tabel 5 sampai tabel 10 diperoleh perkembangan secara keseluruhan dari anak-anak dalam grafik berikut.

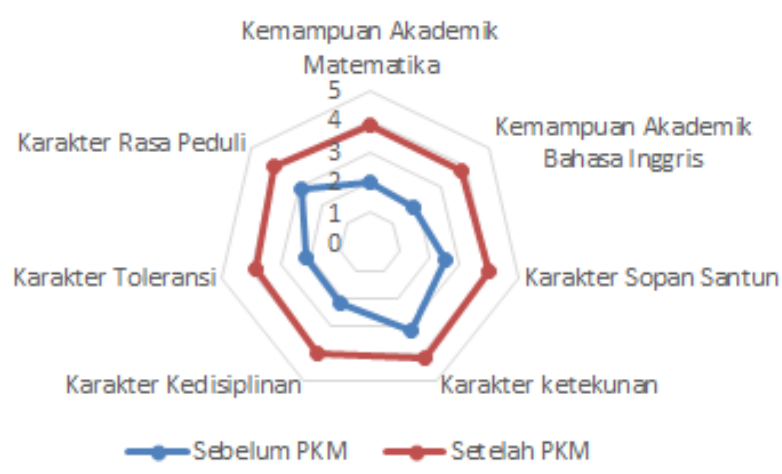

Gambar 5. Grafik Perkembangan Akademik dan Karakter

Dari gambar 3, terlihat bahwa ada perkembangan positif dalam hal akademik dan karakter dari anak-anak peserta PKM Bimbel Pencil Generation. 


\section{SIMPULAN}

a. Pendidikan Karakter merupakan bagian yang sangat penting dalam proses perkembangan didik anak-anak karena dengan membentuk karakter yang baik akan menghasilkan manusia yang berkarakter. Anak-anak yang memiliki karakter sopan santun, ketekunan, kedisiplinan, toleransi, dan rasa peduli akan menjadi anak-anak yang mempunyai daya juang positif.

b. Materi belajar yang diimplementasikan dengan pendidikan karakter dengan metode whole brain teaching membuat anak-anak menjadi aktif di kelas dan adanya komunikasi aktif antara pengajar dan peserta didik. Dengan metode whole brain teaching proses belajar mengajar menjadi tidak menjemukan melainkan menambahkan minat anak dalam belajar sehingga nilai-nilai karakter yang diharapkan dapat diserap anak dengan baik dan dapat mereka terapkan dalam kehidupan sehari-hari.

\section{UCAPAN TERIMA KASIH}

Peneliti mengucapkan terima kasih atas pendanaan pengabdian kepada masyarakat skema Program Kemitraan Masyarakat (PKM) kepada DRPM Kementerian Riset dan Teknologi Tinggi dengan nomor kontrak T/217/L1.3.1/PT.01.03/2019.

\section{DAFTAR PUSTAKA}

[1] Dewi, Yusfita Kumala. 2015. Pendidikan Karakter dalam Pembelajaran Matematika. Math Didactic: Jurnal Pendidikan Matematika. 1(2). 118-124.

[2] Jailani. 2011. Pendidikan Karakter pada Pembelajaran Matematika. Prosiding Seminar Nasional Penelitian, Pendidikan, dan Penerapan MIPA, Fakultas MIPA, Universitas Negeri Yogyakarta. 197-204.

[3] Rahman, Abdul. 2016. Pendidikan Karakter Dalam Pembelajaran Matematika. AKSIOMA Jurnal Pendidikan Matematika. 5(3).
[4] Octavita, Rr. Astri Indriana dan Ria Saraswati. 2017. Integrasi Pendidikan Berkarakter dalam Pembelajaran Bahasa Inggris. Jurnal Terapan Abdimas, Vol 2. 33-40

[5] Wahyanti, C. Murni dan Sutopo, Joko. 2013. Pengembangan Materi Ajar Berbasis Pendidikan Karakter bagi Guru Bahasa Inggris SD di Kecamatan Tembalang. Rekayasa 11(2). 105-110

[6] Nursulistiyo, Eko. 2014. Kajian Metode Power Teaching sebagai Alternatif Metode Pembelajaran Sains di Kelas. JRKPF UAD. 1(1).

[7] Biffle, Chris. 2016. "Whole Brain Teaching Character Education \& Beloved Rascals!". https://www.teacherspayteachers.com/ Product/Whole-Brain-TeachingCharacter-Education-Course-2689547 Diakses pada 18 Juni 2018 Pukul 20.44.

[8] Napfiah, Siti. 2016. Penerapan Metode Pembelajaran Whole Brain pada Mata Kuliah Telaah Matematika SD. Jurnal Pendidikan Matematika. 1(1). 37-46.

[9] Fayogi, S.F., 2017. Teaching SelfIntroduction by Using the Whole Brain Teaching Method. Jurnal Pendidikan dan Pembelajaran, 6(9). 